\title{
The Nero Lucano Pig Breed: Recovery and Variability
}

\author{
Carmelisa Valluzzi ${ }^{1}$, Andrea Rando ${ }^{1}$ (D) Nicolò P. P. Macciotta ${ }^{2}$, Giustino Gaspa ${ }^{3}$ (D) and Paola Di Gregorio ${ }^{1, *}$ \\ 1 Scuola di Scienze Agrarie, Forestali, Alimentari ed Ambientali, University of Basilicata, Via dell'Ateneo \\ Lucano 10, 85100 Potenza, Italy; valluzzi.carmelisa@tiscali.it (C.V.); andrea.rando@unibas.it (A.R.) \\ 2 Dipartimento di Agraria, Sezione Scienze Zootecniche, University of Sassari, Via De Nicola 9, \\ 07100 Sassari, Italy; macciott@uniss.it \\ 3 Dipartimento di Scienze Agrarie, Forestali e Alimentari, University of Torino, Largo Baccini 2, \\ 10095 Grugliasco (TO), Italy; giustino.gaspa@unito.it \\ * Correspondence: paola.digregorio@unibas.it
}

check for updates

Citation: Valluzzi, C.; Rando, A.; Macciotta, N.P.P.; Gaspa, G.; Di Gregorio, P. The Nero Lucano Pig Breed: Recovery and Variability. Animals 2021, 11, 1331. https:// doi.org/10.3390/ani11051331

Academic Editor:

Enrico D'Alessandro

Received: 16 February 2021

Accepted: 4 May 2021

Published: 7 May 2021

Publisher's Note: MDPI stays neutral with regard to jurisdictional claims in published maps and institutional affiliations.

Copyright: (C) 2021 by the authors. Licensee MDPI, Basel, Switzerland. This article is an open access article distributed under the terms and conditions of the Creative Commons Attribution (CC BY) license (https:/ / creativecommons.org/licenses/by/ $4.0 /)$.
Simple Summary: The reduction of biodiversity determines the loss of species and breeds, with the consequent disappearance of production systems, knowledge, cultures and local traditions. The Nero Lucano pig is a native breed of Southern Italy (Basilicata region) recovered, starting from 2001 , because of the high quality of its cured meat products. This study gives a picture of the low genetic variability of this breed. Knowledge of individual inbreeding levels allows for planning of interventions to reduce the negative effects of the low effective population size and, then, improve the efficiency of the actual recovery project.

Abstract: The Nero Lucano (NL) pig is a black coat colored breed characterized by a remarkable ability to adapt to the difficult territory and climatic conditions of Basilicata region in Southern Italy. In the second half of the twentieth century, technological innovation, agricultural evolution, new breeding methods and the demand for increasingly lean meat brought the breed almost to extinction. Only in 2001, thanks to local institutions such as: the Basilicata Region, the University of Basilicata, the Regional Breeders Association and the Medio Basento mountain community, the NL pig returned to populate the area with the consequent possibility to appreciate again its specific cured meat products. We analyzed the pedigrees recorded by the breeders and the Illumina Porcine SNP60 BeadChip genotypes in order to obtain the genetic structure of the NL pig. Results evidenced that this population is characterized by long mean generation intervals (up to $3.5 \mathrm{yr}$ ), low effective population size (down to 7.2) and high mean inbreeding coefficients $\left(\mathrm{F}_{\mathrm{MOL}}=0.53, \mathrm{~F}_{\mathrm{ROH}}=0.39\right.$ ). This picture highlights the low level of genetic variability and the critical issues to be faced for the complete recovery of this population.

Keywords: Nero Lucano pig; Southern Italy; pedigree analysis; inbreeding coefficient; runs of homozygosity $(\mathrm{ROH})$

\section{Introduction}

The Nero Lucano (NL) pig is reared in Basilicata and is characterized by a black coat with rough coarse hair-bristles, mean size, long head with straight nose profile, broughtforward ears of medium length, long and thin legs, lean muscles, thick backfat and low number of newborns per delivery.

This breed is well adapted to the mountain habitat and climate conditions of Basilicata. Due to its rusticity, it is reared outdoors where occasional basic shelters can be found. These pigs are able to exploit feed resources available in the environment (such as thistles, carobs, alfalfa, acorns and bulbs) and occasionally receive a feed integration of common grains [1]. Cured products obtained from NL breed reared in these conditions are strongly appreciated by consumers and are sold under the brand "ANTICO SUINO NERO LUCANO".

In Southern Italy the presence of black pigs can be traced back to 1729 [2]. The pig population consisted of native animals characterized by: black coat, remarkable rusticity 
and modest growth. They had different denominations in relation to the area they belonged to. The representative morphological types were: the Appulo-Lucano, the Calabro-Lucano, the Cavallino and the Italico [3].

In the second post-war period, technological innovations, evolution of agricultural and breeding methods, demand for lean meat by consumers and increasing production by farmers, have gradually determined the substitution of these native breeds with cosmopolitan ones. In 2001, few subjects (maybe six) showing the typical characteristics of the ancient black pig reared in Basilicata were identified. These subjects, thanks to institutions such as the Basilicata Region, the University of Basilicata, the Regional Breeders Association, the Comunità Montana Medio Basento and a group of breeders, were used to recover the Nero Lucano pig breed.

The aim of this work was to obtain a first picture of the genetic structure of NL pig to be used for the analysis of the evolution of this population. For this purpose, we analyzed the available pedigrees of $226 \mathrm{NL}$ pigs and the results of their genotyping at the 61,565 SNPs of the Illumina Porcine SNP60 BeadChip.

\section{Materials and Methods}

\subsection{Animals}

Animal blood samples were collected for the common veterinary controls of commercial pig farms. On this basis, the animals were managed according to the Directive 98/58/EC, as required by the Directive 2010/63/EU regarding the protection of animals used for scientific purposes. Samples were collected from 226 Nero Lucano pigs (209 sows and 17 boars), born between 2006 and 2014 and belonging to a pedigree of 281 individuals. DNA was isolated by using the NucleoSpin DNA QuickPure kit (Macherey Nagel, Duren, Germany).

\subsection{Pedigree Analysis}

The software ENDOG v.4.8 [4] was used to evaluate pedigree completeness index; number of maximum, complete and equivalent generations; number of ancestors and their contribution to the genetic variability; and inbreeding coefficients ( $\left.F_{P E D}\right)$. Effective population size $(\mathrm{Ne})$ was estimated via individual increase in inbreeding $[5,6]$

\subsection{DNA Analyses}

DNA samples were genotyped with the Illumina Porcine SNP60 BeadChip v2. The distribution of SNPs per chromosome was updated according to Illumina PorcineSNP60 v2.0 Manifest File (https: / / support.illumina.com/downloads/porcinesnp60-v2_product_ files.html, accessed on 23 October 2019).

The quality control was accomplished by using PLINK v.1.07 [7] to include samples with a minimum genotyping rate of $95 \%$ and SNPs with a minimum $95 \%$ call rate. Hardy-Weinberg equilibrium and individual inbreeding coefficients based on molecular information $\left(\mathrm{F}_{\mathrm{MOL}}\right.$ ) were calculated by considering only polymorphic loci (Minimum Allele Frequency, MAF > 0) located on autosomal chromosomes.

The runs of homozygosity $(\mathrm{ROH})$ were obtained by defining a sliding 'window' of 50 SNPs, a maximum of one heterozygote and one missing call were allowed in the 'window', with at least 50 SNPs per 'window'. Individual inbreeding values based on $\mathrm{ROH}$ $\left(\mathrm{F}_{\mathrm{ROH}}\right)$ were calculated as $\mathrm{F}_{\mathrm{ROH}}=\Sigma \mathrm{L}_{\mathrm{ROH}} / \mathrm{L}$, where $\Sigma \mathrm{L}_{\mathrm{ROH}}$ is the total $\mathrm{ROH}$ length per individual and $\mathrm{L}$ is the autosomal genome length $(2265.77 \mathrm{Mb}$, according to Sscrofa 11.1 chromosome assembly).

Gene location was accomplished by referring to NCBI Sus scrofa Annotation Release 106 (https: / / www.ncbi.nlm.nih.gov/genome/annotation_euk/Sus_scrofa/106/, accessed on 30 December 2020).

Gene ontology enrichment analysis was performed by using DAVID 6.8 database [8,9] (https: / / david.ncifcrf.gov / home.jsp, accessed on 30 December 2020). 


\section{Results}

\subsection{Pedigree Analysis}

By using the data of the 'Registro Anagrafico dei Tipi Genetici Autoctoni della Specie Suina' (Italian Registrar for Autochthonous Swine Breeds) and ENDOG v.4.8 software, it was possible to construct a pedigree of 281 pigs, distributed across 18 farms, characterized by a completeness index decreasing rapidly upstream the grandparents' generation (Table 1 , Figure S1) due to the incomplete registration at the level of third and fourth generations back. In this pedigree, the 281 pigs were traced across three generations, the maximum number of generations traced was five, and the mean equivalent generations value was 1.39 .

Table 1. Pedigree completeness index for the known generations in Nero Lucano pigs.

\begin{tabular}{cc}
\hline Generation & Completeness Index \\
\hline Parents & 0.851 \\
Grandparents & 0.461 \\
Great-grandparents & 0.072 \\
gg-grandparents & 0.003 \\
\hline
\end{tabular}

The average generation interval was 2.88 years, with a maximum for sire-sire interval (3.5 years), and a minimum for dam-dam one (2.32 years) (Table 2$)$.

Table 2. Average generation intervals in Nero Lucano pigs.

\begin{tabular}{ccc}
\hline Interval & $\boldsymbol{N}$ & Years \pm SD \\
\hline sire-sire & 13 & $3.503 \pm 1.469$ \\
sire-dam & 62 & $3.250 \pm 1.320$ \\
dam-sire & 13 & $3.187 \pm 0.836$ \\
dam-dam & 62 & $2.328 \pm 0.778$ \\
Total & 150 & $2.886 \pm 1.190$ \\
\hline
\end{tabular}

Analysis of the pedigree showed that the mean inbreeding $\left(\mathrm{F}_{\mathrm{PED}}\right)$ and relatedness values were 0.057 and 0.054 , respectively. A total of 81 inbred animals, representing $28.82 \%$ of the whole pedigree, were characterized by a mean $F_{P E D}$ value of 0.197 . These individuals were the result of mating between full siblings (13), half siblings (36), and parent-offspring (32). The high amount of parent-offspring mating is likely to be the consequence of both long generation intervals and the free rearing system. Data separated according to the three generations traced are shown in Table 3.

Table 3. Inbreeding coefficient, relatedness and effective population size of the three generations traced in Nero Lucano pigs.

\begin{tabular}{ccccccc}
\hline Generation & N Pigs & Mean F & \% Inbred & Mean F for Inbred & Mean Relat. & Eff.Pop. Size \\
\hline 0 & 42 & 0 & - & - & 0.0238 & - \\
1 & 153 & 0.043 & 17.6 & 0.245 & 0.0565 & 11.5 \\
2 & 86 & 0.109 & 62.8 & 0.174 & 0.0643 & 7.2 \\
\hline
\end{tabular}

The more than doubled $F_{\text {PED }}$ value $(0.043 \rightarrow 0.109)$ from generation 1 to generation 2 was determined by a strong increase $(0.176 \rightarrow 0.628)$ in the percentage of inbred animals. Such an increase was, however, coupled with a decreased mean $F_{P E D}$ value per inbred pig $(0.245 \rightarrow 0.174)$. The effective population size $(\mathrm{Ne})$ was very low in both inbred generations (11.5 and 7.2, respectively). In addition, the whole current gene pool was explained by 42 ancestors, with only 8 explaining the $53.27 \%$ of the genetic variability (Figure S2). 


\subsection{Microarray Analysis}

A total of 226 out of the 281 pigs belonging to the pedigree were genotyped by using the Illumina PorcineSNP60 BeadChip. These individuals were born between November 2006 and January 2014 and according to ENDOG pedigree analysis were distributed in the three generations traced as reported in Table 4.

Table 4. Number of Nero Lucano pig DNA samples analyzed with Illumina PorcineSNP60 BeadChip within each generation.

\begin{tabular}{ccc}
\hline \multirow{2}{*}{ Generation } & \multicolumn{2}{c}{$N$ Pigs } \\
\cline { 2 - 3 } & Pedigree & DNA Samples \\
\hline 0 & 42 & 6 \\
1 & 153 & 132 \\
2 & 86 & 85 \\
\hline
\end{tabular}

The distribution of SNPs per chromosome was updated according to the Illumina PorcineSNP60 v2.0 Manifest File by using PLINK (Table S1). All the animals passed the data quality control (genotyping rate $>95 \%$ ), and the available 61565 SNPs were reduced to 60600 by the minimum call rate of $95 \%$.

In the analyzed NL pigs, $12.7 \%$ of the autosomal SNPs were monomorphic (Minimum Allele Frequency, MAF $=0$ ), whereas $51.38 \%$ were characterized by an MAF $>0.05$ (Table S2, Figure S3).

Hardy-Weinberg analysis was accomplished for generations 1 and 2 with the exclusion of generation 0 for which only six individuals were available (Table 4). The percentage of SNPs that were not in the Hardy-Weinberg equilibrium ranged from $5.03 \%$ in generation 1 to $6.76 \%$ in generation 2 . The excess of homozygotes was responsible for the observed Hardy-Weinberg disequilibrium in $57.53 \%$ of cases in generation 1 and in $88.57 \%$ of cases in generation 2 (Figure S4). These results are in agreement with the threefold increase of inbred animals percentage from generation 1 to generation 2 , as evidenced by pedigree analysis (see Table 3).

The inbreeding coefficients based on SNP frequencies ( $\mathrm{F}_{\mathrm{MOL}}$ ) showed very high average values of $0.53 \pm 0.10$ and $0.53 \pm 0.12$ for generations 1 and 2, respectively. Since SNP frequencies estimates on only six samples are insufficiently reliable, $\mathrm{F}_{\mathrm{MOL}}$ value for generation 0 was not considered. As shown in Figure 1, more than two thirds of pigs are characterized by values higher than 0.50 (about $70 \%$ of generation 1 and $73 \%$ of generation 2). The distributions of $\mathrm{F}_{\mathrm{MOL}}$ were very similar in both generations and characterized by similar minimum (0.11 and 0.14$)$ and identical mean $(0.53)$ and maximum values (0.74).

\subsection{Analysis of Runs of Homozygosity}

A search for runs of homozygosity $(\mathrm{ROH})$ in the $226 \mathrm{NL}$ pigs identified a total of 12159 $\mathrm{ROH}$, covering about $38 \%$ of the genome (calculated as mean of total $\mathrm{ROH}$ length per individual / $2265.77 \mathrm{Mb}$ autosomal genome length). The higher numbers of $\mathrm{ROH}$ were observed on SSC1 (1258 for a $29.41 \%$ coverage) and SSC14 (1118 for a $41.44 \%$ coverage), while the maximum observed coverage $(51.20 \%)$ was on SSC4. The distribution of ROH was homogeneous among the size classes $2-4 \mathrm{Mb}, 4-8 \mathrm{Mb}, 8-16 \mathrm{Mb}$ and $>16 \mathrm{Mb}$, while those with a length less than $2 \mathrm{Mb}$ were poorly represented (only $6.74 \%$ of total $\mathrm{ROH}$ ) (Table S3, Figure S5). In our population, the number of $\mathrm{ROH}$ per pig varied from a minimum of 11 to a maximum of 100 with a mean value of $53.8 \pm 11.02$ (Figure S6), and the total ROH length per animal varied from a minimum of $30.66 \mathrm{Mb}$ to a maximum of $1446.9 \mathrm{Mb}$ with a mean value of $864.67 \pm 269.61 \mathrm{Mb}$. 


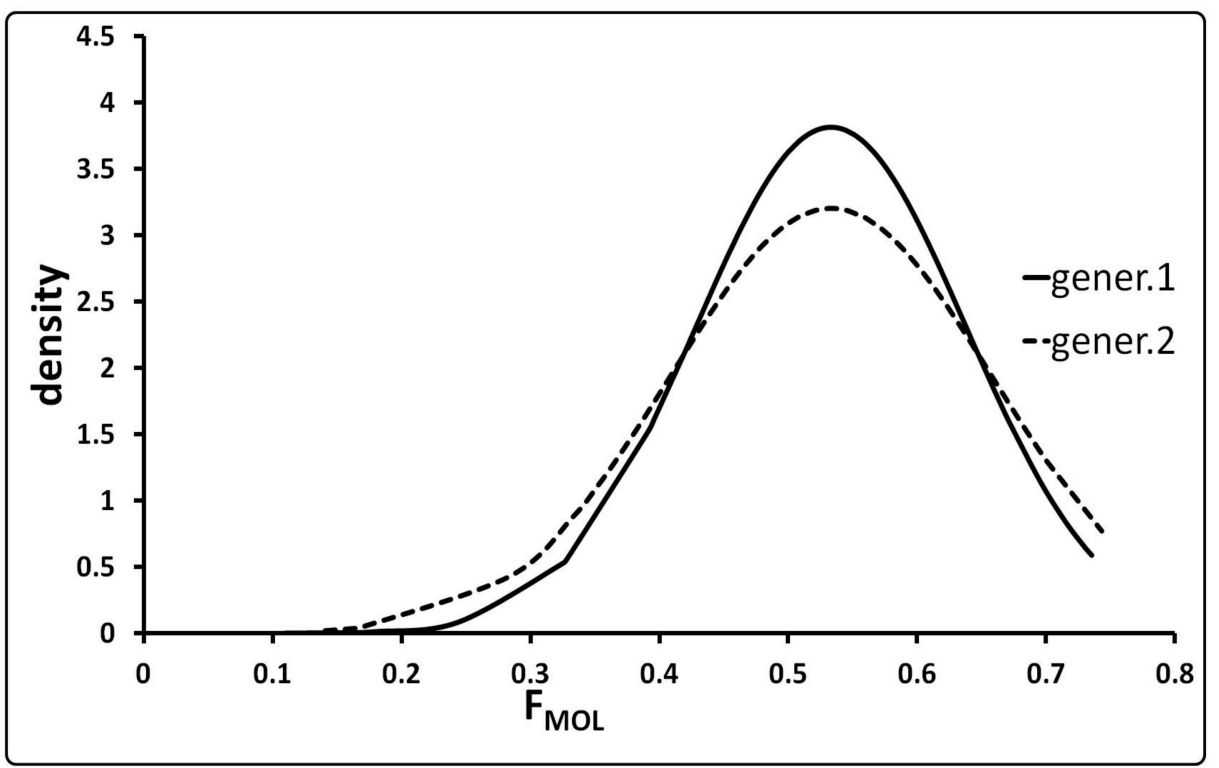

Figure 1. Distribution of the $\mathrm{F}_{\mathrm{MOL}}$ (inbreeding coefficient using molecular polymorphisms) values in generations 1 and 2 of Nero Lucano pig.

In order to identify possible NL chromosomal conserved regions, all the $\mathrm{ROH}$ were overlapped according to chromosome position defining the maximum shared segment of each ROH. As a result, 1408 consensus match segments shared by a minimum of 30 to a maximum of 214 pigs were obtained. This number was restricted to $171 \mathrm{ROH}$ segments by considering the following thresholds: $\mathrm{ROH}$ shared by more than $30 \%$ of the analyzed pigs, longer than $500 \mathrm{~kb}$ and with at least 20 SNPs. Such segments were distributed on 17 of the 18 autosomes since no $\mathrm{ROH}$ satisfying the above- mentioned threshold conditions were observed on SSC3 (Table S4). The longer common ROH was located on SSC15 ( $5749.139 \mathrm{~kb}$, shared by $93 / 226$ pigs), whereas the most represented one was located on SSC14, (1856.209 kb, shared by 214/226 pigs).

Gene search in the most represented $\mathrm{ROH}$ per each chromosome was accomplished by using Sscrofa11.1 Genome Assembly. The 230 identified genes (Table S5) were analyzed for gene ontology by using DAVID 6.8 database. According to the results, five genes (CDS1, INPP5J, ITPR3, MTMR3 and PIP4K2A) are involved in the phosphatidylinositol signaling pathway that is engaged in several biological processes such as: membrane trafficking and endosome dynamics, protein trafficking, cell adhesion, polarization and migration [10-12]. In addition, six genes (FGF9, KSR1, NF1, PLA2G3, RGL2 and SYNGAP1) are involved in the Ras signaling pathway that is responsible for control of cell proliferation, migration and survival [13]. Furthermore, 11 genes are involved in 10 biological processes (Table 5). Noteworthy, some of these genes are involved in more than one biological process or pathway.

Table 5. Genes associated in biological processes by DAVID software.

\begin{tabular}{ccc}
\hline GO Term & Biological Process & Genes \\
\hline GO:0042992 & negative regulation of transcription factor import into nucleus & RAB23, NF1 \\
GO:0046888 & negative regulation of hormone secretion & LIF, OSM \\
GO:0007265 & Ras protein signal transduction & KSR1, NF1, SYNGAP1 \\
GO:0007260 & tyrosine phosphorylation of Stat3 protein & LIF, OSM \\
GO:0043410 & positive regulation of MAPK cascade & KSR1, LIF, OSM \\
GO:2000786 & positive regulation of autophagosome assembly & KIAA1324, PIP4K2A \\
GO:0045835 & negative regulation of meiotic nuclear division & LIF, OSM \\
GO:0001675 & acrosome assembly & TMF1, PLA2G3 \\
GO:0048711 & positive regulation of astrocyte differentiation & BIN1, LIF \\
GO:0048169 & regulation of long-term neuronal synaptic plasticity & NF1, SYNGAP1 \\
\hline
\end{tabular}


Though methods and parameters for $\mathrm{ROH}$ definition differ according to authors, none of the most represented $\mathrm{ROH}$ per each chromosome in NL pig overlapped with common $\mathrm{ROH}$ identified in other Italian black pig breeds $[14,15]$. However, when extending the comparison to the most common $171 \mathrm{NL} \mathrm{ROH}$, only four partial $\mathrm{ROH}$ overlaps were identified (Table 6). These overlapping regions contain genes whose activities are related to reproduction and production traits such as spermatogenesis (SPATA5) [16], locomotory behavior, meat smell and taste (NOVA1) [14,17], protection from UVB radiation (CALB1) [18], cellular growth and division (DDX10) [19] and lipid composition traits (DECR1) [20].

Table 6. Genes located in common $\mathrm{ROH}$ shared by Nero Lucano and Italian black pigs.

\begin{tabular}{|c|c|c|c|c|c|}
\hline SSC & $N^{1}$ & Shared ROH Region & Breed $^{2}$ & Reference & NCBI Genes in Shared Region \\
\hline 4 & 77 & $45.15-46.82$ & $\mathrm{AC}$ & [15] & $\begin{array}{c}\text { CALB1, DECR1, TMEM64, NBN, } \\
\text { NECAB1, C4H8orf88, OTUD6B, } \\
\text { SLC26A7, TMEM55A }\end{array}$ \\
\hline 7 & 141 & $72.73-73.13$ & CA & [14] & NOVA1 \\
\hline 8 & 136 & $100.93-101.22$ & $\mathrm{AC}, \mathrm{CS}$ & [14] & SPATA5 \\
\hline 9 & 165 & $37.15-37.81$ & $\mathrm{AC}$ & [15] & DDX10, C9H11orf87 \\
\hline
\end{tabular}

${ }^{1}$ number of NL pigs that show the ROH. ${ }^{2} \mathrm{AC}=$ Appulo Calabrese, $\mathrm{CA}=$ Casertana, $\mathrm{CS}=$ Cinta Senese.

The inbreeding coefficients based on $\mathrm{ROH}$ extension $\left(\mathrm{F}_{\mathrm{ROH}}\right)$, obtained for the generations 0,1 and 2, were characterized by the distributions shown in Figure 2 and by mean values of $0.36 \pm 0.12,0.39 \pm 0.11$ and $0.38 \pm 0.13$, respectively.

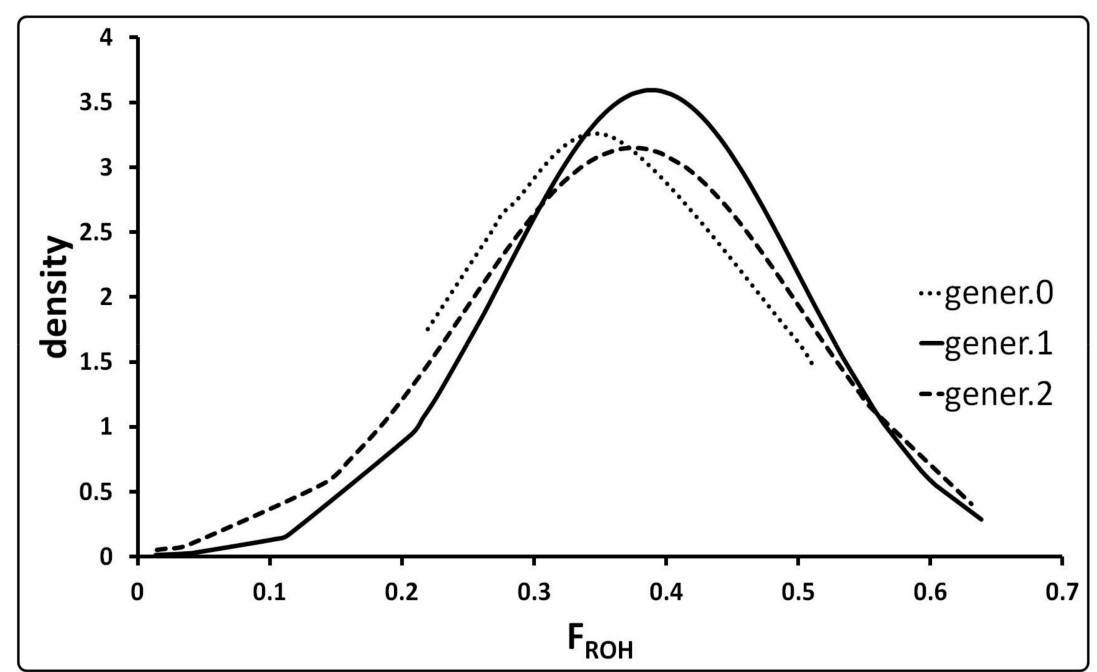

Figure 2. Distribution of the $\mathrm{F}_{\mathrm{ROH}}$ (inbreeding coefficient using Runs of Homozygosity) values in the three generations of Nero Lucano pig.

The correlation coefficients between $\mathrm{F}_{\mathrm{MOL}}$ and $\mathrm{F}_{\mathrm{ROH}}$ were very high: 0.97 and 0.98 for generations 1 and 2, respectively. On the contrary, correlations of $\mathrm{F}_{\mathrm{MOL}}$ and $\mathrm{F}_{\mathrm{ROH}}$ with $F_{P E D}$ were very low varying from a minimum of 0.10 to a maximum of 0.14 .

\section{Discussion}

We analyzed the genetic structure of the Nero Lucano (NL) pig, an endangered small population reared in Southern Italy, about ten years after its recovery. At the time of the sample collection the pedigree of this population was characterized by 281 animals distributed across 18 farms. Though results could be affected by the decreasing completeness of the pedigree, this population was characterized by long generation intervals (Table 2), apparently low mean inbreeding value (0.057) and small effective population sizes (Table 3 ). In particular, the generation intervals in NL pig were, in some cases, more than twice those observed for cosmopolitan breeds and were characterized by higher values for the sire 
pathways rather than for the dam ones [21-23]. Furthermore, the mean F value shows a strong tendency to increase from a generation to another (from 0.043 to 0.109 ) (Table 3). A marked contribution to the increase of the F value could be due to the high amount of parent-offspring mating, an obvious consequence of both long generation intervals and free rearing system. In addition, the increase of the inbreeding coefficient was, of course, coupled with the reduction of the effective population size $(\mathrm{Ne})$. According to the FAO [24] guidelines for the management of small populations at risk, an acceptable Ne value should be around 50 in order to avoid increase in inbreeding coefficient and for a good population fitness.

Results obtained by the Illumina PorcineSNP60 BeadChip genotyping evidenced that: (i) the percentage of SNPs having an MAF > 0.05 was lower $(51.38 \%)$ than those observed in three cosmopolitan breeds (Duroc 67.5\%, Landrace 80.6\% and Yorkshire 80.4\%) [25]; (ii) SNPs in Hardy-Weinberg disequilibrium were mainly due to excess of homozygotes; (iii) the inbreeding coefficients based on molecular data $\left(\mathrm{F}_{\mathrm{MOL}}\right)$ were very high and comparable with those observed in some small, closed and endangered Spanish (Guadyerbas 0.80 and Torbiscal 0.74) and Chinese (Wuzhishan 0.44) populations [26-28]; and (iv) the overlapping of the $\mathrm{F}_{\mathrm{MOL}}$ curves in the two inbred generations could be the consequence of breeders activities (for example, boar exchanges) to avoid an excessive increase of inbreeding.

The coverage of the NL pig genome with $\mathrm{ROH}$ was about $38 \%$, a very high value when compared with an average of $23 \%$ reported for cosmopolitan (Duroc, Hampshire, Large White and Landrace) and Asian (Meishan, Jianquhai and Xiang) breeds [29]. Furthermore, short $\mathrm{ROH}(<2 \mathrm{Mb})$, determined by recombination events over generations that disrupt long stretches of DNA, were poorly represented (6.74\%). These results are in agreement with recent inbreeding events in a small population [30,31]. Of course, it cannot be excluded that the observed low percentage of short $\mathrm{ROH}$ was the result of the limited capability of their detection by the used medium-density marker panel [29,32].

A search for genes in the most represented $\mathrm{ROH}$ per each chromosome and in the $\mathrm{ROH}$ segments overlapping between NL and other Italian black pig breeds allowed the identification of 230 and 13 genes, respectively. Among these, since the NL pigs are characterized by a low number of newborns per delivery (according to our data, mean value of $6.6 \pm 1.9$ ) and their cured products are strongly appreciated, two genes, Leukemia Inhibitory Factor (LIF) and 2,4-Dienoyl-CoA Reductase 1 (DECR1), are, according to us, particularly worthy of consideration. In fact, the former shows polymorphisms associated with litter size variation in pig $[33,34]$, and the latter polymorphisms associated with variation in lipid composition traits [20].

As expected, according to the $\mathrm{ROH}$ coverage of the genome, the observed high value of $\mathrm{F}_{\mathrm{ROH}}$ (mean 0.37 ) is a further indication of the low level of genetic variability of the NL pig population confirming results obtained with both pedigree and molecular data.

The comparison of the inbreeding coefficients, calculated according to pedigree, molecular data and runs of homozygosity, showed the lowest values for $F_{\text {PED }}$ and the highest values for $\mathrm{F}_{\mathrm{MOL}}$. Explanation of the low level of $\mathrm{F}_{\mathrm{PED}}$ can be found in the low completeness of the pedigree and in the fact that the starting generation is composed of animals with $\mathrm{F}_{\mathrm{PED}}=0$ by default, underestimating the real level of inbreeding. The observed mean $\mathrm{F}_{\mathrm{ROH}}$ value for generation $0(0.36)$ is a clear indication that animals chosen for the recovery of the NL pig were already inbred. Consequently, $\mathrm{F}_{\mathrm{MOL}}$ and $\mathrm{F}_{\mathrm{ROH}}$ seem to be more reliable estimates of inbreeding coefficient values. We observed strong correlation coefficients between $\mathrm{F}_{\mathrm{MOL}}$ and $\mathrm{F}_{\mathrm{ROH}}$ and low correlation coefficients of $\mathrm{F}_{\mathrm{MOL}}$ and $\mathrm{F}_{\mathrm{ROH}}$ with $\mathrm{F}_{\mathrm{PED}}$ in NL pig. Similar correlation values, based on a very high number of samples belonging to complete pedigrees, were also obtained for Landrace and Large White breeds [35].

All the results presented in this paper highlight the low level of genetic variability of the current NL pig population which, ten years after its recovery, is still at risk. In this contest the possibility of intervention by using individuals already belonging to the NL pig population is confined only to avoid an excessive inbreeding coefficient increase by using, 
for example, boars showing the lowest $\mathrm{F}_{\mathrm{ROH}}$ and/or $\mathrm{F}_{\mathrm{MOL}}$ values and by exchanging them among breeders. In this way, the repeated use of the same boar on strongly genetically related dams of the following generations will be prevented. Furthermore, the use of sires belonging to the "great family of black Southern Italy pig breeds" (for example, ApuloCalabrese, Nero Siciliano and Sarda), could be considered as a possible extreme approach. In this case, as stated by FAO [24], the aim is to carefully plan the increase of the genetic variability of NL pig preserving the typical characteristics of the breed and its products.

\section{Conclusions}

The results presented in this study highlight the critical issues to be faced for the complete recovery of the Nero Lucano pig breed. Low effective population size, long generation intervals and high inbreeding values depict a population still at risk about ten years after its recovery.

Supplementary Materials: The following are available online at https:/ /www.mdpi.com/article/10 .3390/ani11051331/s1, Figure S1. Pedigree completeness up to 4 generations back in Nero Lucano pig., Figure S2. Effect of number of ancestors on genetic variability in Nero Lucano pig. Figure S3. SNP distribution per chromosome and MAF classes in Nero Lucano pig. Figure S4. SNPs in HardyWeinberg disequilibrium due to excess of heterozygotes and homozygotes in generations 1 and 2 of the Nero Lucano pig pedigree. Figure S5. Distribution of the $\mathrm{ROH}$ per chromosome and length in Nero Lucano pig. Figure S6. Distribution of the ROH in the Nero Lucano pig population Table S1. distribution of SNPs per chromosome updated according to the Illumina PorcineSNP60 v2.0 Manifest File modified on 26/4/2019, Table S2. Distribution of SNPs per chromosome and MAF classes in Nero Lucano pig. Table S3. Distribution of the ROH per chromosome and ROH classes in Nero Lucano pig. Table S4. Distribution of the ROH present in more than $30 \%$ of the analyzed Nero Lucano pigs, longer than $500 \mathrm{~kb}$, and with at least 20 SNPs. Table S5. Genes located in the most represented ROH per each chromosome of the Nero Lucano pig (NCBI Release 106, Chromosome Assembly Sscrofa 11.1).

Author Contributions: Conceptualization and Methodology, P.D.G. and A.R.; Investigation, P.D.G. and C.V.; Funding acquisition, A.R.; Formal analysis, P.D.G. and G.G.; Writing-Original Draft Preparation, P.D.G.; Writing—Review and Editing, P.D.G., A.R. and N.P.P.M. All authors have read and agreed to the published version of the manuscript.

Funding: This work was supported by PSR of the Basilicata Region 2014-2020, Misura 10, sottomisura 10.2. "Conservazione e uso sostenibile delle risorse genetiche in agricoltura" (Conservation and sustainable use of genetic resources in agricolture), project "(TGA) - Standardizzazione, stabilizzazione e valorizzazione dei tipi genetici autoctoni suini, ovicaprini ed equini" (TGAStandardization, stabilization and enhancement of native pig, sheep, goat and equine genetic types); CUP C36C18000160006.

Institutional Review Board Statement: Not applicable. Samples collected by veterinary doctors for the routine analyses established by law for the common veterinary controls of commercial pig farms.

Data Availability Statement: The data analyzed during the current study are available from the corresponding author on reasonable request.

Acknowledgments: We thank the Basilicata Region Breeders Association (Associazione Regionale Allevatori, Basilicata) for collaboration in blood samples collection and relationship with breeders.

Conflicts of Interest: The authors declare no conflict of interest.

\section{References}

1. Maiorano, G. Swine production in Italy and research perspectives for the local breeds. Slovak J. Anim. Sci. 2009, 42, 159-166.

2. Stanga, I. Suinicoltura Pratica; Hoepli, U., Ed.; Editore Libraio della Real Casa: Milano, Italy,, 1915.

3. Croce, L. Il Problema Zootecnico del Mezzogiorno Continentale d'Italia; Tipografia Mario Nucci: Potenza, Italy, 1930.

4. Gutierrez, J.P.; Goyache, F. A note on ENDOG: A computer program for analysing pedigree information. J. Anim. Breed. Genet. 2005, 122, 172-176. [CrossRef]

5. Gutierrez, J.P.; Cervantes, I.; Molina, A.; Valera, M.; Goyache, F. Individual increase in inbreeding allows estimating realised effective sizes from pedigrees. Genet. Sel. Evol. 2008, 40, 359-378. [CrossRef] 
6. Gutierrez, J.P.; Cervantes, I.; Goyache, F. Improving the estimation of realized effective population sizes in farm animals. J. Anim. Breed. Genet. 2009, 126, 327-332. [CrossRef] [PubMed]

7. Purcell, S.; Neale, B.; Todd-Brown, K.; Thomas, L.; Ferreira, M.A.R.; Bender, D.; Maller, J.; Sklar, P.; de Bakker, P.I.W.; Daly, M.J.; et al. PLINK: A toolset for whole-genome association and population-based linkage analysis. Am. J. Hum. Genet. 2007, 81, 559-575. [CrossRef]

8. Huang, D.W.; Sherman, B.T.; Lempicki, R.A. Systematic and integrative analysis of large gene lists using DAVID Bioinformatics Resources. Nat. Protoc. 2009, 4, 44-57. [CrossRef] [PubMed]

9. Huang, D.W.; Sherman, B.T.; Lempicki, R.A. Bioinformatics enrichment tools: Paths toward the comprehensive functional analysis of large gene lists. Nucleic Acids Res. 2009, 37, 1-13. [CrossRef] [PubMed]

10. Corvera, S. Phosphatidylinositol 3-kinase and the control of endosome dynamics. Traffic 2001, 2, 859-866. [CrossRef] [PubMed]

11. Simonsen, A.; Wurmser, A.E.; Emr, S.D.; Stenmark, H. The role of phosphoinositides in membrane transport. Curr. Opin. Cell Biol. 2001, 13, 485-492. [CrossRef]

12. Weiner, O.D.; Neilsen, P.O.; Prestwich, G.D.; Kirschner, M.W.; Cantley, L.C.; Bourne, H.R. A PtdInsP(3)- and Rho GTPase-mediated positive feedback loop regulates neutrophil polarity. Nat. Cell Biol. 2002, 4, 509-513. [CrossRef]

13. Gurung, A.B.; Bhattacharjee, A. Significance of Ras signaling in cancer and strategies for its control. Oncol. Hematol Rev. 2015, 11, 147-152. [CrossRef]

14. Munoz, M.; Bozzi, R.; García-Casco, J.; Nunez, Y.; Ribani, A.; Franci, O.; García, F.; Skrlep, M.; Schiavo, G.; Bovo, S.; et al. Genomic diversity, linkage disequilibrium and selection signatures in European local pig breeds assessed with a high density SNP chip. Sci. Rep. 2019, 9, 13546. [CrossRef]

15. Schiavo, G.; Bovo, S.; Bertolini, F.; Dall'Olio, S.; Costa, L.N.; Tinarelli, S.; Gallo, M.; Fontanesi, L. Runs of homozygosity islands in Italian cosmopolitan and autochthonous pig breeds identify selection signatures in the porcine genome. Livest. Sci. 2020, 240, 104219. [CrossRef]

16. Sujit, K.M.; Singh, V.; Trivedi, S.; Singh, K.; Gupta, G.; Rajender, S. Increased DNA methylation in the spermatogenesis-associated (SPATA) genes correlates with infertility. Andrology 2020, 8, 602-609. [CrossRef] [PubMed]

17. Van Son, M.; Kent, M.P.; Grove, H.; Agarwal, R.; Hamland, H.; Lien, S.; Grindflek, E. Fine mapping of a QTL affecting levels of skatole on pig chromosome 7. BMC Genet. 2017, 18, 85. [CrossRef] [PubMed]

18. Liu, K.; Zhao, J.; Yang, L.; Guan, M.; Yuan, L.; Geng, Y. Protective effects of calbindin D28K on the UVB radiation induced apoptosis of human lens epithelial cells. Int. J. Mol. Med. 2020, 45, 1793-1802. [CrossRef] [PubMed]

19. Behdani, E.; Ghaderi-Zefrehei, M.; Rafeie, F.; Bakhtiarizadeh, M.; Roshanfeker, H.; Fayazi, J. RNA-Seq Bayesian Network Exploration of Immune System in Bovine. Iran. J. Biotechnol. 2019, 17, e1748. [CrossRef]

20. Ramirez, O.; Quintanilla, R.; Varona, L.; Gallardo, D.; Díaz, I.; Pena, R.N.; Amills, M. DECR1 and ME1 genotypes are associated with lipid composition traits in Duroc pigs. J. Anim. Breed. Genet. 2014, 131, 46-52. [CrossRef]

21. Melka, M.G.; Schenkel, F. Analysis of genetic diversity in four Canadian swine breeds using pedigree data. Can. J. Anim. Sci. 2010, 90, 331-340. [CrossRef]

22. Tang, G.Q.; Xue, J.; Lian, M.J.; Yang, R.F.; Liu, T.F.; Zeng, Z.Y.; Jiang, A.A.; Jiang, Y.Z.; Zhu, L.; Bai, L.; et al. Inbreeding and genetic diversity in three imported swine breeds in china using pedigree data. Asian-Australas. J. Anim. Sci. 2013, 26, 755-765. [CrossRef]

23. Krupa, E.; Zakova, E.; Krupová, Z. Evaluation of Inbreeding and Genetic Variability of Five Pig Breeds in Czech Republic. Asian-Australas. J. Anim. Sci. 2015, 28, 25-36. [CrossRef]

24. FAO. Secondary guidelines for development of farm animal genetic resources management plans. In Management of Small Populations at Risk; FAO: Rome, Italy, 2000.

25. Grossi, D.A.; Jafarikia, M.; Brito, L.F.; Buzanskas, M.E.; Sargolzaei, M.; Schenkel, F.S. Genetic diversity, extent of linkage disequilibrium and persistence of gametic phase in Canadian pigs. BMC Genet. 2017, 18, 6. [CrossRef]

26. Saura, M.; Fernandez, A.; Rodrıguez, M.C.; Toro, M.A.; Barragan, C.; Fernandez, A.I.; Villanueva, B. Genome-Wide estimates of coancestry and inbreeding in a closed herd of ancient Iberian pigs. PLoS ONE 2013, 8, e78314. [CrossRef]

27. Gomez-Raya, L.; Rodriguez, C.; Barragan, C.; Silio, L. Genomic inbreeding coefficients based on the distribution of the length of runs of homozygosity in a closed line of Iberian pigs. Genet. Sel. Evol. 2015, 47, 81. [CrossRef]

28. Wang, L.; Mu, Y.; Xu, L.; Li, K.; Han, J.; Wu, T.; Liu, L.; Gao, Q.; Xia, Y.; Hou, G.; et al. Genomic analysis reveals specific patterns of homozygosity and heterozygosity in inbred pigs. Animals 2019, 9, 314. [CrossRef] [PubMed]

29. Bosse, M.; Megens, H.-J.; Madsen, O.; Paudel, Y.; Frantz, L.A.F.; Schook, L.B.; Crooijmans, R.P.M.A.; Groenen, M.A.M. Regions of homozygosity in the porcine genome: Consequence of demography and the recombination landscape. PLoS Genet. 2012, 8, e1003100. [CrossRef] [PubMed]

30. Iacolina, L.; Stronen, A.V.; Pertoldi, C.; Tokarska, M.; Norgaard, L.S.; Munoz, J.; Kjærsgaard, A.; Ruiz-Gonzalez, A.; Kaminski, S.; Purfield, D.C. Novel graphical analyses of runs of homozygosity among species and livestock breeds. Int. J. Genomics 2016, 2016, 2152847. [CrossRef]

31. Ceballos, F.C.; Joshi, P.K.; Clark, D.W.; Ramsay, M.; Wilson, J.F. Runs of homozygosity: Windows into population history and trait architecture. Nat. Rev. Genet. 2018, 19, 220-234. [CrossRef] [PubMed]

32. Ferencakovic, M.; Solkner, J.; Curik, I. Estimating autozygosity from high-throughput information: Effects of SNP density and genotyping errors. Genet. Sel. Evol. 2013, 45, 42. [CrossRef] 
33. Spotter, A.; Drogemuller, C.; Hamann, H.; Distl, O. Evidence of a new leukemia inhibitory factor-associated genetic marker for litter size in a synthetic pig line. J. Anim. Sci. 2005, 83, 2264-2270. [CrossRef]

34. Ding, Y.; Ding, C.; Wu, X.; Wu, C.; Qian, L.; Li, D.; Zhang, W.; Wang, Y.; Yang, M.; Wang, L.; et al. Porcine LIF gene polymorphisms and their association with litter size traits in four pig breeds. Can. J. Anim. Sci. 2020, 100, 85-92. [CrossRef]

35. Zanella, R.; Peixoto, J.O.; Cardoso, F.F.; Cardoso, L.L.; Biegelmeyer, P.; Cantao, M.E.; Otaviano, A.; Freitas, M.S.; Caetano, A.R.; Ledur, M.C. Genetic diversity analysis of two commercial breeds of pigs using genomic and pedigree data. Genet. Sel. Evol. 2016, 48, 24. [CrossRef] [PubMed] 